Scientia Marina 70(4)

December 2006, 585-592, Barcelona (Spain)

ISSN: 0214-8358

\title{
Sperm ultra-structure and spermiogenesis in Syllis krohni (Polychaeta: Syllidae), with some observations on its reproductive biology
}

\author{
ELENA LEPORE ${ }^{1}$, MARGHERITA SCISCIOLI ${ }^{1}$, MARIA MASTRODONATO ${ }^{1}$, \\ MIRIAM GHERARDI ${ }^{1}$, ADRIANA GIANGRANDE ${ }^{2}$ and LUIGI MUSCO ${ }^{2}$ \\ ${ }^{1}$ Dipartimento di Zoologia, Università di Bari, 70125 Bari, Italy. \\ ${ }^{2}$ Dipartimento di Scienze e Tecnologie Biologiche e Ambientali, Università di Lecce, 73100 Lecce, Italy. \\ E-mail: luigi.musco@unile.it
}

SUMMARY: Syllidae show a wide spectrum of both reproductive strategies and sperm types. Analysis of their reproductive patterns could drastically change the presently accepted taxonomic hierarchy of the group. To further contribute to the knowledge of Syllidae we have described the sperm ultra-structure and the spermiogenesis of Syllis krohni (Ehlers, 1864). Mature sperm has a cone-shaped acrosome whose distal end is notched by a trough that transversely encircles its anterior portion. During spermiogenesis, the acrosomal vesicle undergoes modifications leading to its final shape with a posterior opening. The nucleus appears flattened anteriorly and forms a cleft that surrounds the proximal centriole in its distal region. A 9+2 flagellar axoneme is observed. Up to five mitochondria surround the distal centriole. The spermatozoon of S. krohni can be ascribed to the ect-aquasperm type that is typical in species having external fertilisation and appears to be very similar in appearance to that of the congeneric species thus far investigated. The main difference is in the shape of the acrosome, which is more elongated and as long as the nucleus. Reproduction of syllids seems to be conservative within sub-families, and the sperm morphology can probably help in phylogenetic reconstruction. External fertilisation is a widespread strategy within the genus Syllis, probably leading to a substantial similarity in sperm morphology being maintained. It is hypothesised, however, that within the same sperm type linked to a particularly reproductive strategy, the acrosome ultra-structure can be indicative of phylogeny.

Keywords: sperm morphology, ultra-structure, Polychaeta, Syllidae, phylogeny.

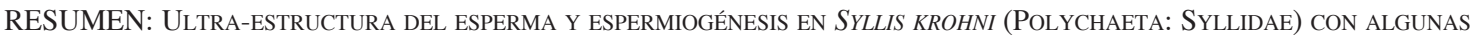
OBSERVACIONES DE SU BIOLOGÍA REPRODUCTIVA. - La familia Syllidae muestra un amplio espectro de variación tanto de la estrategia reproductiva como del tipo de espermatozoide. La jerarquía taxonómica de la familia actualmente aceptada podría cambiar drásticamente después de una profunda análisis de las modalidades reproductivas. Con el objetivo de dar aún una mayor contribución al conocimiento de la biología de la familia Syllidae, en este trabajo se ha estudiado la ultra-estructura del espermatozoide y la espermatogénesis de algunos individuos de Syllis krohni Ehlers 1864. El espermatozoide maduro presenta un acrosoma cónico, cuye parte distal está inciso a través de una fisura que transversalmente circunda su parte anterior. Durante la espermatogénesis, la vesícula del acrosoma se modifica hasta su forma final en la que es presente de una apertura posterior. El núcleo es aplanado en su parte anterior y en la región distal presenta una incisión que circunda el centríolo proximal. Se ha observado un axonema flagelar de estructura $9+2$. Hasta cinco mitocondrias circunda el centríolo distal. El espermatozoide de $S$. krohni puede ser adscrito al tipo ect-aquasperma que es típico en aquellas especies que tienen una fecundación externa y que aparece muy similar a las de las especies congenéricas estudiadas hasta el momento. La principal diferencia se encuentra en la forma del acrosoma que es más largo que en las especies similares y tan largo como el núcleo. La reproducción de Sílidos parece ser conservativa en el interior de las subfamilias y probablemente la morfología del espermatozoide puede ayudar en la reconstrucción filogenético. La fecundación externa es una estrategia muy difundida dentro del género Syllis y esto probablemente lleva a mantener una similitud substancial en la morfología del espermatozoide. Se formula la hipótesis, de todas formas, que en el interior del mismo tipo de espermatozoide y en la estrategia reproductiva, la ultra-estructura del acrosoma puede ser indicativa de filogenia.

Palabras clave: morfología espermatozoides, ultra-estructura, Polychaeta, Syllidae, filogenia. 


\section{INTRODUCTION}

The family Syllidae is one of the most diverse within Polychaeta (Annelida), numbering about 667 species distributed in a large array of habitats, especially in the littoral fringe (see Musco and Giangrande, 2005 and literature cited therein). The family is usually divided into four subfamilies (Syllinae, Eusyllinae, Autolytinae and Exogoninae), but its taxonomic hierarchy is under debate. In fact, several authors (Franke, 1999; Nygren, 1999; Glasby, 2000) have pointed out the ambiguity of the present classification and the pressing need for a phylogenetic analysis of the whole family also based on molecular analysis and reproductive patterns.

From a reproductive point of view a large array of strategies have been reported (Franke, 1999; San Martín, 2003) and a strong link between phylogeny and reproductive modes has been inferred (Franke, 1999; Nygren, 1999; San Martín, 2005). After the pioneering studies by Malaquin (1893) and Potts (1911) on the diversity of reproduction modes of Syllidae, further studies were carried out by Okada (1929, 1937) for the sub-families Syllinae and Autolytinae, and by Schiedges $(1979,1980)$ and Gidholm (1965, 1966) for the sub-family Autolytinae.

The majority of the syllid species reproduce by epitoky (Malaquin, 1893; Schroeder and Hermans, 1975; Franke and Pfannenstiel, 1984; Garwood, 1991; Franke, 1999), which may be divided into epigamy and schizogamy (stolonisation). In epigamy the whole animal undergoes the modification into the epitokous form (Wissocq, 1970a, b, c; Daly, 1975; Garwood, 1991). In schizogamy only a part of the individual (usually the posterior one) undergoes the modification into the epitokous form, the so-called stolon, which is the free swimming stage carrying the germinal products. There are two types of schizogamy (Gidholm, 1967; Estapè and San Martín, 1991; Garwood, 1991): scissiparity (some of the existing segments in the stock are transformed into a stolon) and gemmiparity (new segments proliferate and produce stolons).

Epitoky is known in several species of Syllinae, Eusyllinae and Exogoninae. The suppression of epitoky is often associated with hermaphroditism (Westheide, 1984; Garwood, 1991; Bührmann et al., 1996; Giangrande, 1997; Kuper and Westheide, 1997) and external gestation (Mastrodonato et al., 2003). The majority of the species are dioic and usu- ally lack an evident sexual dimorphism in both atokous and epitokous individuals (San Martín, 2003).

Thus, it is not surprising that such a wide spectrum of reproductive strategies is accompanied by a variety of different sperm types. According to Jamieson and Rouse (1989), all the sperm categories, ect-aquasperm, ent-aquasperm and introsperm, are encountered within syllids. However, though the family consists of a great number of species, information about spermatogenesis and the ultra-structure of their spermatozoa is scarce. In fact, the ultrastructural organisation of spermatozoa has been analysed in Salvatoria (=Grubea) clavata (Franzén, 1974), Syllis pigmentata (as Typosyllis pulchra), Syllis sp (as Typosyllis sp) (Jamieson and Rouse, 1989; Heacox and Schroeder, 1981), Autolytus sp and Calamyzas amphictenicola (Franzén, 1982), Neopetitia (=Petitia) amphophthalma (Bührmann et al., 1996), Sphaerosyllis hermaphrodita (Kuper and Westheide, 1997), Exogone naidina and E. dispar (Giangrande et al., 2002). See Licher (1999) and San Martín (2003) for the resolution of synonymies.

Due to the high diversity in the reproductive modes of Syllidae, the study of the sperm ultrastructure and its correlation with their reproductive biology is particularly interesting in order to better define the taxonomic hierarchy within them. The sperm structure may be useful for the reconstruction of the phylogenetic patterns of the family (Franke, 1999).

To contribute to the knowledge of the diversity of spermatozoa in the Syllidae family, we studied the sperm ultra-structure of an additional species of the genus Syllis: S. krohni.

\section{MATERIAL AND METHODS}

\section{Target species and study area}

Syllis krohni [the original name S. krohnii was recently emended by Licher (1999)] is widely distributed in the Atlantic-Mediterranean region and commonly collected within the algae of the photophilic hard substrata (San Martín, 2003), including some human-impacted areas and harbours (Musco, personal observations). During the early reproductive phase the adult specimens undergo schizogamy by scissiparity. The resulting stolon (Chaetosyllis type) is characterised by a typically bilobate head 
(dicerous) with two un-articulated appendages (antennae), four eyes (two ventral and two dorsal), capillary natatory chetae and the non-development of the feeding-related organs (San Martín, 2003).

Male specimens of $S$. krohni were collected in shallow water (0.5-1 $\mathrm{m}$ depth) in the harbour of Bari (4108'01'N, 1652'06”E, south Adriatic Sea, Apulia, Italy) in May 2005 by scraping the algal substrate. The study area suffers from poor hydrodynamism and wastewater discharge (mainly organic) from both urban and harbour activities, and experiences strong annual temperature and salinity variations. The identification of the collected specimens (both atokous and epitokous) was carried out using Licher (1999) and San Martín (2003) as identification guides.

\section{Methodology}

For transmission electron microscopy investigations, specimens were fixed in a mixture of $2.5 \%$ glutaraldehyde, cacodylate buffer $(0.4 \mathrm{M})$ and filtered seawater ( $\mathrm{pH}$ 7.4). Subsequently they were post-fixed for $1 \mathrm{~h}$ in a mixture of $1.0 \% \mathrm{OsO}_{4}$ and sea water at $4^{\circ} \mathrm{C}$, rinsed in sea water, dehydrated with a graded series of acetone, and embedded in Araldite (Taab, Aldermaston, England) for sectioning. The ultra-thin sections were cut with an LKB ultratome, contrasted with 5\% uranyl acetate in $50 \%$ ethanol and lead citrate in distilled water, and examined with an EM 109 microscope (Zeiss, Oberkochen, Germany). Semi-thin sections (1 $\mu \mathrm{m}$ thick) were heat-stained with toluidine blue borate (Millonig, 1976).

\section{RESULTS}

\section{Morphology of stolons and stocks}

The analysed specimens (both stocks and stolons) of $S$. krohni corresponded well to the morphological descriptions by Licher (1999) and San Martín (2003), apart from the greater dimensions of the stocks examined in the present study (length about $15 \mathrm{~mm}$ vs 6.9 $\mathrm{mm}$; width about $0.8 \mathrm{~mm}$ vs $0.6 \mathrm{~mm}$ ).

The collected individuals produced one stolon consisting of $c a$. 20-30 segments full of gametes. The stolon head bore four eyes and appeared typically bilobate (dicerous) (Fig. 1). The stolon gut was atrophic and tended to disappear due to compression

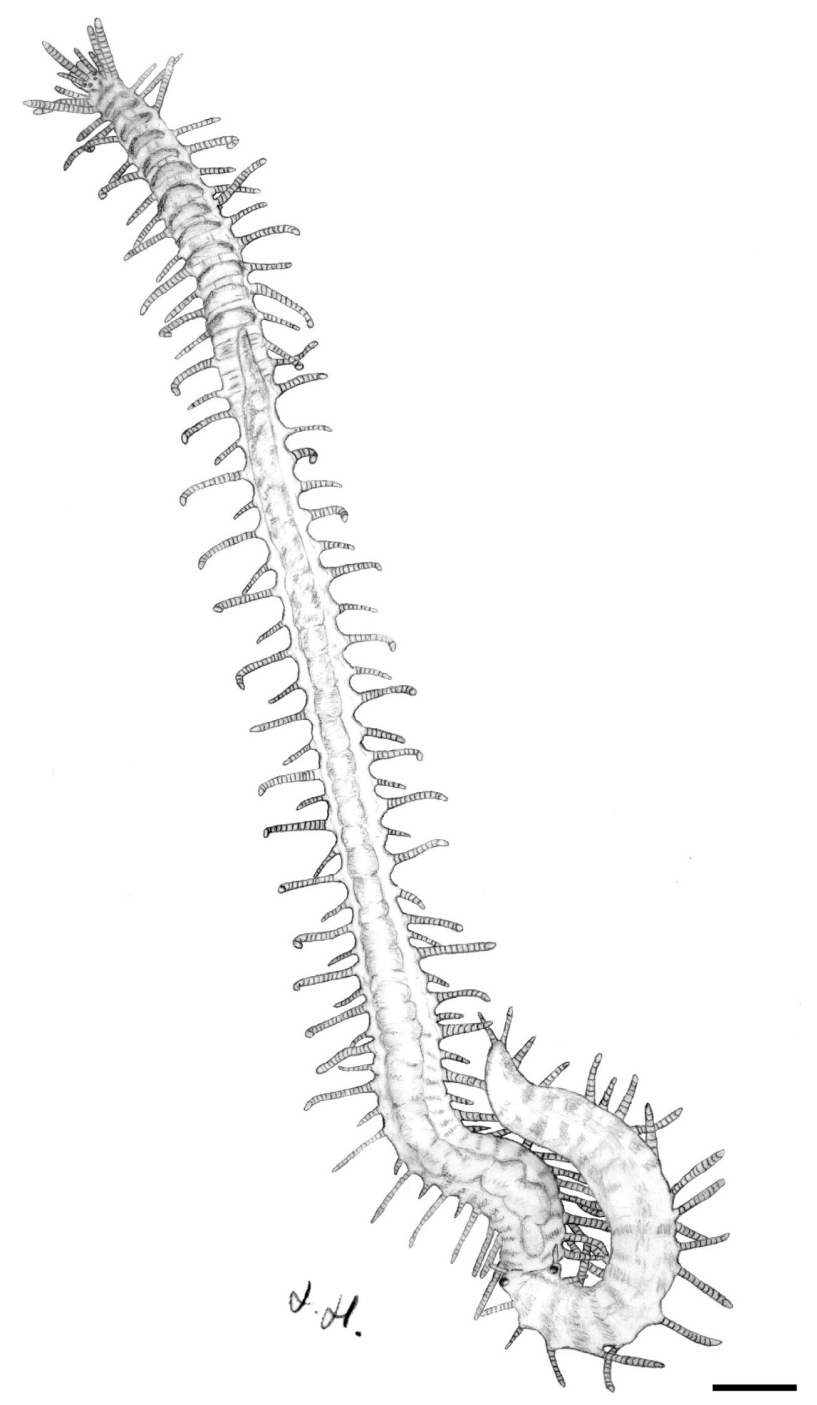

FIG. 1 - Male stock of Syllis krohni bearing a stolon at the posterior end. Scale bar, $1 \mathrm{~mm}$.

by the mass of germinal cells. The nervous ganglia were present but the musculature was reduced. (Fig. 2 A). In contrast the gut of the stock was full of ingested material, among which some diatoms together with chaetae and uncini of a sabellid polychaete were easily recognisable.

Some irregularly shaped cells with numerous long cilia were observed in the epidermis of the stolon (Fig. 2B, C).

Two masses of germinal elements were located at the sides of the atrophic gut (Fig. 2A). The stolons containing exclusively spermatozoa were orangecoloured, whereas others containing germinal elements at various stages of maturation were whitish in colour. In the coelomic cavity of the latter, spermatocytes, spermatids and numerous mature sperms were present. 

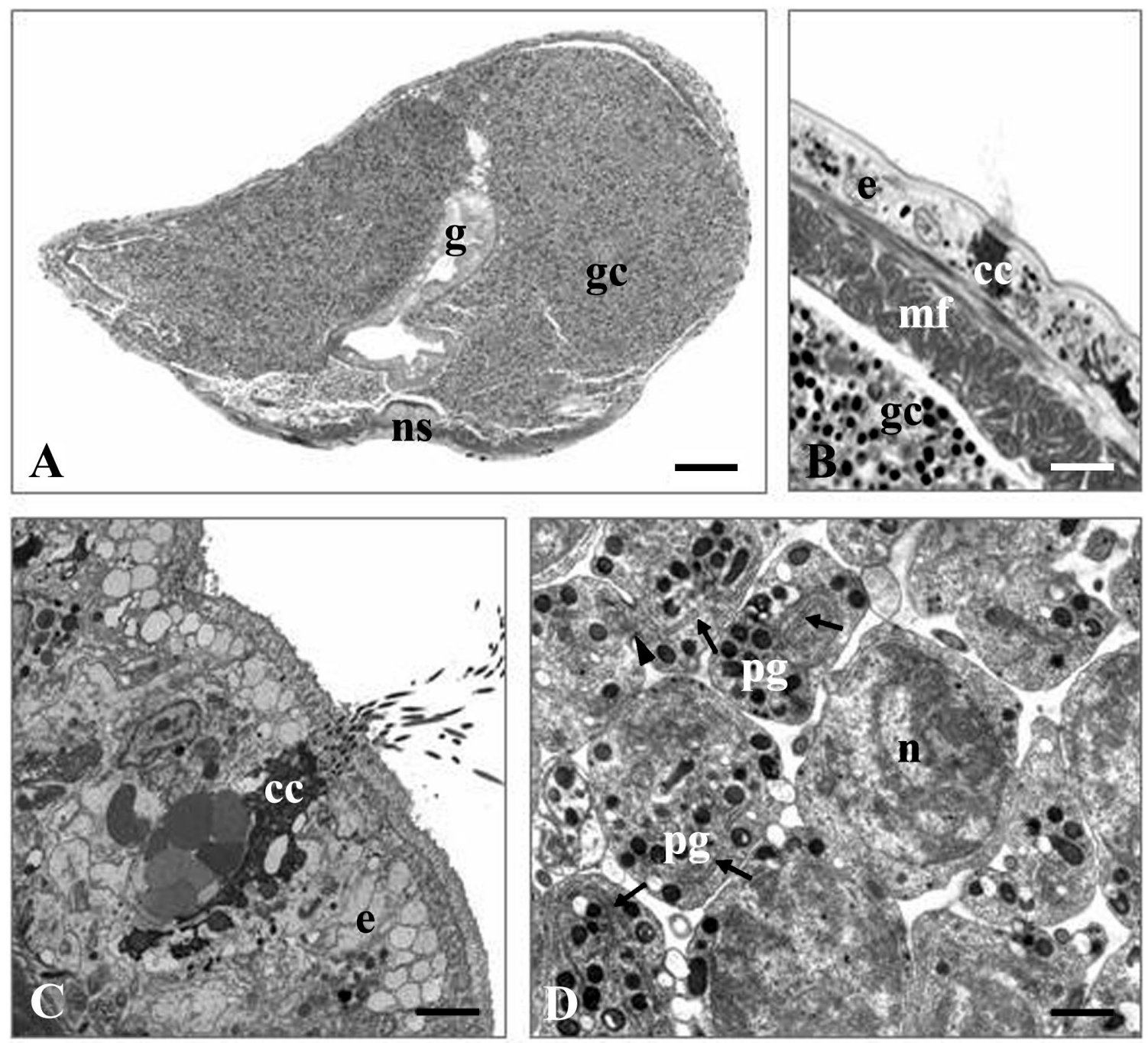

FIG. 2 - A, transverse semi-thin section showing the coelomic cavity full of male germinal cells (gc). nervous system (ns); gut (g). Scale bar, $60 \mu \mathrm{m}$. B, semi-thin section showing a ciliary cell (cc) in the epidermis (e). muscle fibres (mf); male germinal cells (gc). Scale bar, $15 \mu \mathrm{m}$. $\mathrm{C}$, ultra-thin section of the epidermis (e) in which a ciliary cell (cc) is visible. Scale bar, $3.5 \mu \mathrm{m}$. D, ultra-thin section of spermatocytes. nucleus (n); ergastoplasmic cisternae (arrows); proacrosomal granules (pg); intercellular bridge (arrowhead). Scale bar, $1.2 \mu \mathrm{m}$.

\section{Morphology of the germinal cells}

The spermatocytes were irregularly shaped probably due to their closely packed arrangement and some of them were joined by cytoplasmic bridges (Fig. 2 D). The nucleus was large and elliptical and contained loose chromatin. The Golgi system, some mitochondria and ergastoplasmic cisternae were easily recognizable within the cytoplasm (Fig. 2 D). Some proacrosomal granules which give rise to the acrosome were observed in the spermatocytes and in the early spermatids (Figs 2 D, 3 A). The proacrosomal granules were variable in number and had an electrondense peripheral ring, a less dense inner region and an electron-dense core (Fig. $3 \mathrm{~A}$ ); the nucleus was still roundish and contained loose chromatin.
During the process of spermiogenesis the proacrosomal granules merged, giving rise to a long, narrow structure that formed a kind of cup beneath the plasmic membrane (Fig. 3 B). While the acrosomal vesicle became longer and thinner, it moved to the anterior pole of the nucleus. In this phase a homogeneous content defined by an electron-dense peripheral area was visible (Fig. 3 C). In this same area an expansion was formed, later causing the formation of the sub-acrosomal space (Fig. 3 D). The acrosomal vesicle changed, gradually becoming bell-shaped in the late spermatids (Fig. 4 A). The sub-acrosomal space of the sperm was filled with granular material and had a core occupied by filamentous substance (Fig. 4 A, B, C, D). In the basal region of the acrosomal vesicle, closest to the nucle- 
us, it was possible to observe a small opening with an accumulation of electron-dense material (Fig. 4A-C). The mature sperms had an elongated coneshaped acrosome $(1.8 \mu \mathrm{m})$. The distal end of the acrosome was notched by a trough that transversely encircled its anterior portion (Fig. 4B). The trough resembled a borderline separating the acrosomal cup from the acrosome proper. Another trough was present at its base (Fig. 4B, C).

The formation of the acrosome occurred simultaneously with the condensation of the nucleus. The latter began with the irregular accumulation of chromatin in several areas within the nuclear membrane (Fig. 3A-D). The condensation proceeded from the periphery towards the centre of the nucleus (Figs 2D; 3A-D); in the mature sperm it appeared as a cylindrical mass of roughly granular chromatin, subsequently becoming compact and strongly electron-dense. The nucleus of the mature sperm was cylindrical (barrel-shaped) and measured $1 \mu \mathrm{m}$ in diameter and $1 \mu \mathrm{m}$ in length. It appeared flattened in its anterior part, where it remained in contact with the acrosome. In its distal region the nucleus formed a cleft that surrounded the proximal centriole (Fig. 4B, C). The centrioles were located at the base of the nucleus in the opposite position to the acrosome (Fig. 4C). The centrioles and the flagellum already appeared in the spermatids. A 9+2 flagellar axoneme was formed by the distal centriole. Up to five mitochondria surrounding the distal centriole were visible at the base of the nucleus (Fig. 4E).
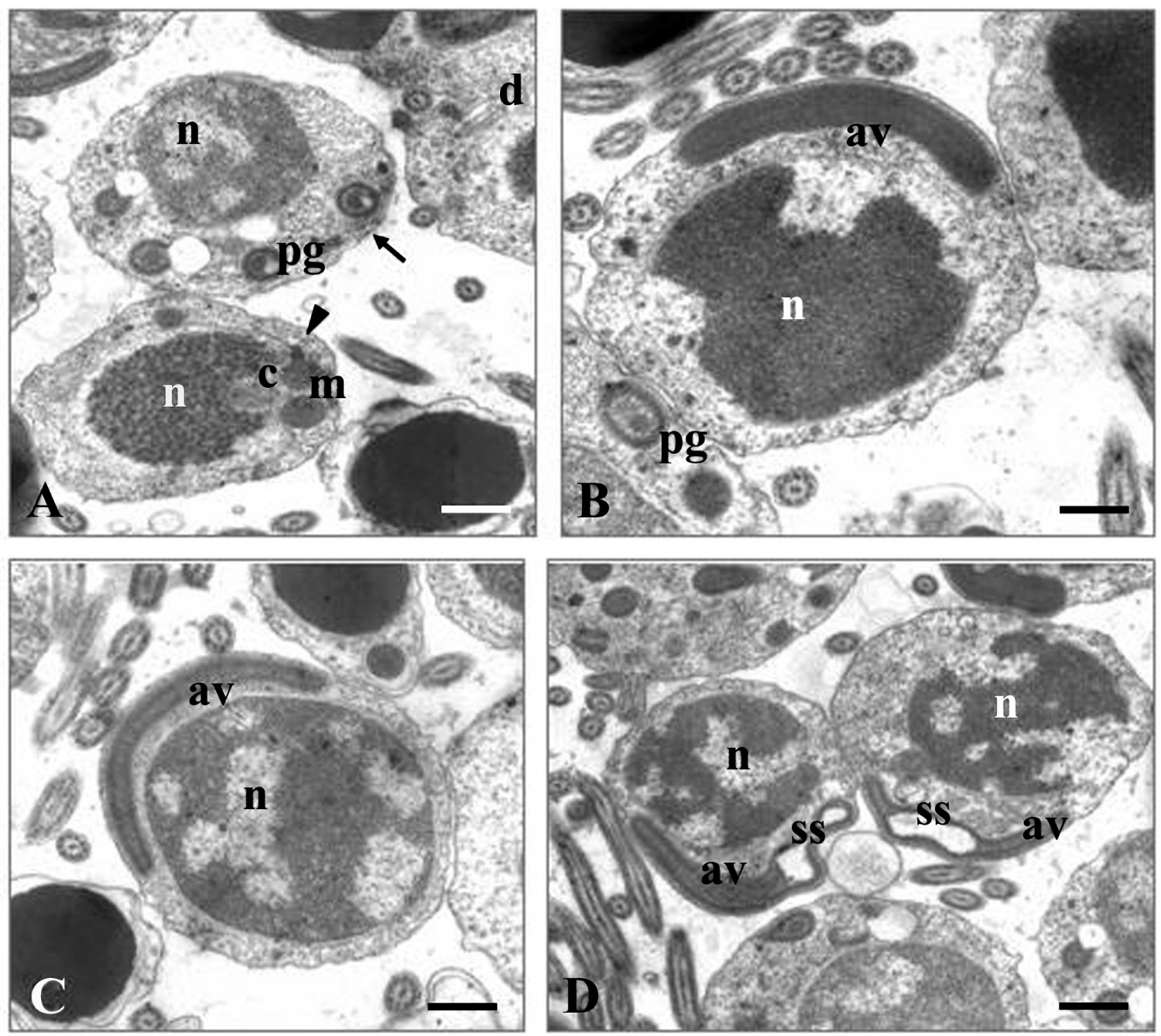

FIG. 3 - Ultra-thin sections. A, spermatocytes (arrow) and early spermatid (arrowhead); nucleus (n); proacrosomal granules (pg); mitochondria (m); centriole (c); dictyosomes (d). Scale bar, $0.6 \mu \mathrm{m}$. B, early spermatid in which the acrosomal vesicle (av) is formed by the proacrosomal granules (pg) fusion. nucleus (n). Scale bar, $0.4 \mu \mathrm{m}$. C, next maturation stage in an early spermatid. nucleus (n); acrosomal vesicle (av). Scale bar, $0.5 \mu \mathrm{m}$. D, early spermatids showing the formation of the sub-acrosomal space (ss). nucleus (n); acrosomal vesicle (av). Scale bar, $0.6 \mu \mathrm{m}$. 

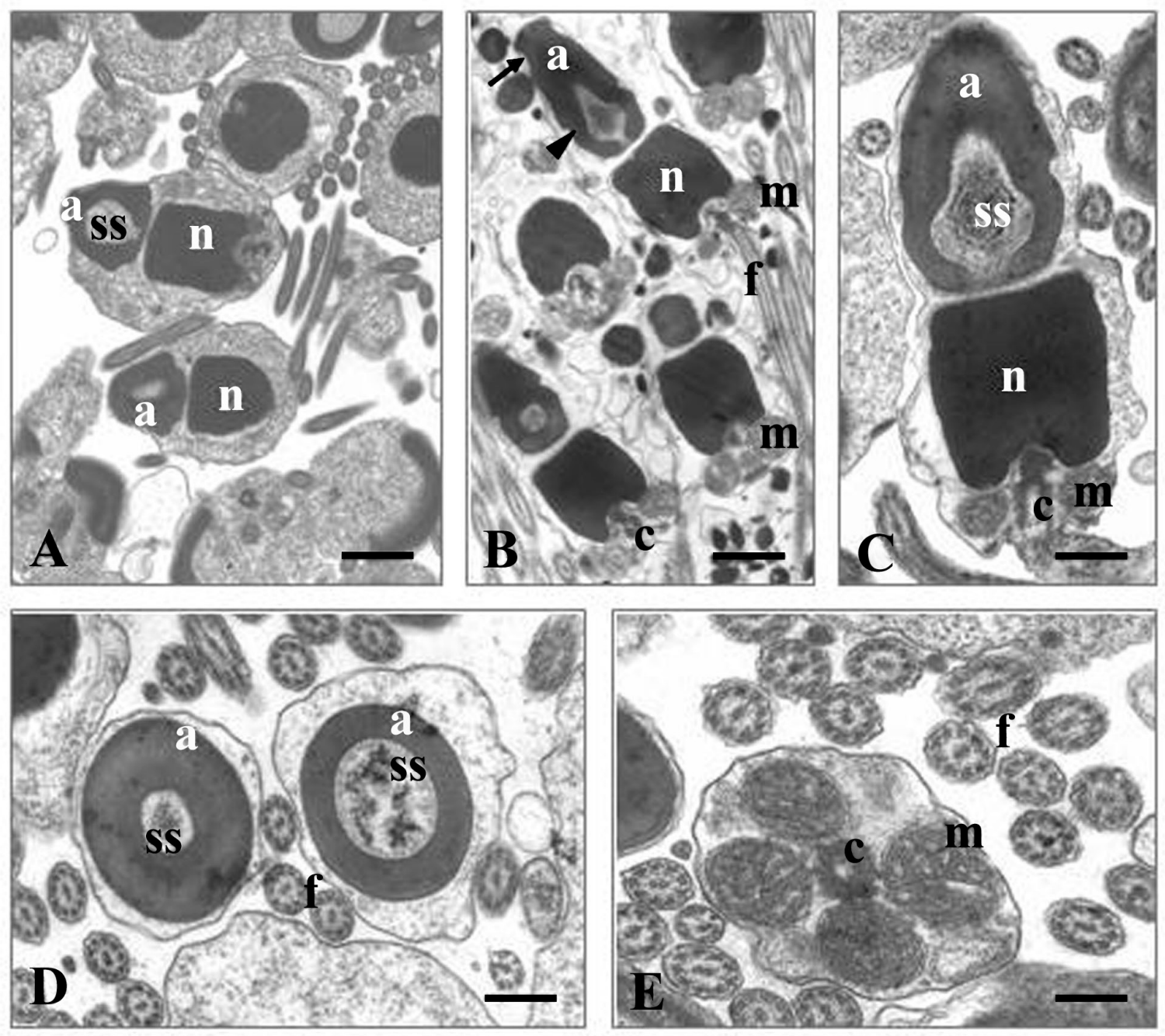

FIG. 4 - Ultra-thin sections. A, late spermatids: a bell-shaped acrosome (a) with granular and filamentous sub-acrosomal material (ss) and nucleus (n) with condensed chromatin. Scale bar, $1.12 \mu \mathrm{m}$. B, C, spermatozoa: fully formed acrosome (a) with the notch indicating the trough marking the junction between acrosome and acrosomal cup (arrow); another notch is present near the basal region of the acrosome (arrowhead); sub-acrosomal space (ss); nucleus (n); mitochondria (m); centrioles (c); flagellum (f). Scale bar (B), $0.8 \mu \mathrm{m}$; (C), $0.4 \mu \mathrm{m}$. D, cross section at two levels of the acrosome (a) showing the different dimensions of the sub-acrosomal space (ss); flagella (f). Scale bar, $0.35 \mu \mathrm{m}$. E, transverse view of mitochondria (m) surrounding the distal centriole (c). flagella (f). Scale bar, $0.25 \mu \mathrm{m}$.

\section{DISCUSSION}

The morphology-based taxonomic examination of the herein analysed specimens of S. krohni (shape and distribution pattern of chaetae, aciculae and cirri, general morphology and colour pattern) revealed a complete correspondence to the available descriptions of this species. As for the greater dimensions of the stocks of our specimens, it must be stressed that, though the specimens described by Licher (1999) and San Martín (2003) were morpho-metrically identical, Licher (1999) clearly states that the specimen that he described was smaller than usual.

An interesting feature observed in the stolon of the examined species is the epidermal structure provided by cilia. Ciliated structures have commonly been reported in stocks and stolons of syllids (Autolytinae), particularly in the prostomial region (San Martín, 2003), but further studies are needed to clarify their function. We suggest that, because the brief life of the stolon is exclusively devoted to sexual reproduction, the cells with groups of long cilia observed along its body surface may be in some way useful in reproduction, maybe as sensorial organs.

Moreover, the presence of undigested residuals (chaetae and uncini) within the posterior portion of the gut of the stock (atokous), possibly belonging to an interstitial form of Jasmineira (Sabellida: Polychaeta), is particularly interesting because $S$. 
krohni has been previously indicated to be herbivorous (Giangrande et al., 2000).

Spermatozoa of $S$. krohni, which can be ascribed to the ect-aquasperm type (sensu Jamieson and Rouse, 1989), appear very similar in morphology to the thus far investigated species of the Syllis genus. The similarity is related to the general shape of the nucleus, mid-piece and internal structure of the acrosome. The difference is in the dimension of the apical part of the acrosome, which is more developed in S. krohni than in congeneric species, so the whole structure appears longer than the nucleus.

However, the acrosomal internal organisation, particularly the presence of a fibrillar electron dense material in the sub-acrosomal space, can be a stronger indication of similarity. The basal invagination of the acrosomal vesicle forming the sub-acrosomal space in Syllis is a common feature in polychaete sperms (Jamieson and Rouse, 1989; Rice, 1992). In S. krohni as well as in the ect-aquasperm of Syllis sp and S. pigmentata (Heacox and Schroeder, 1981; Jamieson and Rouse, 1989), only a small opening is retained between the sub-acrosomal space and the underlying nucleus, and the subacrosomal material within the enclosed cavity is differentiated as an ellipsoidal with a number of electron-dense thick filaments.

The general morphology of the sperm of $S$. krohni is in accordance with the existence of external fertilisation, as expected from the presence of swarming stolons. This reproductive strategy is considered as the most ancestral (sensu Franke, 1999) reproductive mode in Syllidae.

From a phylogenetic point of view, various authors consider the general reproduction pattern of syllids to be conservative within sub-families (Garwood, 1991; Franke, 1999; Nygren, 1999). In this case the sperm morphology can also probably help in the phylogenetic reconstruction. However, accepting phylogenetic constraint as the sole structural designer of sperms may be dangerous. It is highly probable that ecology and ethology play a similarly important role. This could be seen in the sub-family Exogoninae: the species belonging to Salvatoria and Exogone so far examined are very similar in sperm morphology (ent-aquasperm), and they also have similar reproductive behaviour (external brooders). By contrast, sperm of species belonging to the same genus may be different most probably due to the different colonised habitat and reproductive behaviour. The difference in the sperm morphology between Sphaerosyllis hystrix (dioic and usually epibiotic, having a typical intro-sperm) and S. hermaphrodita (hermaphroditic and interstitial, having an extremely modified intro-sperm) fits this last case (Franzén, 1956; Kuper and Westheide, 1997; Giangrande et al., 2000).

In Syllidae, the ect-aquasperm type has exclusively been observed in the three Syllis species examined so far. It can be hypothesised that as external fertilisation is a more widespread strategy within the Syllis genus, this can lead to maintaining a substantial similarity in sperm morphology. It would be interesting therefore to examine the few species of the genus that have been reported as brooders (e.g. S. vivipara) and other Syllinae belonging to the closely related genera.

Sperm morphology can be indicative of phylogeny within species having the same sperm type. An example occurs within the family Sabellidae, where the similarity of the acrosome within ectaquasperms of different species can be indicative of a shared phylogeny (Patti et al., 2003). Even though the presently limited available data prevent any generalisation, the substantial similarity between acrosomal internal features observed in sperms within the genus Syllis seems to confirm this hypothesis.

Although the internal structure of the acrosome can be indicative of affinity among congeneric species sharing a common reproductive strategy, the difference in the acrosomal morphology (acrosomal elongation) observed here could be indicative of phylogeny within the Syllis genus. According to the morphology-based classification of Licher (1999), S. pigmentata and S. krohni belong to different groups (complexes) within the same genus; in anticipation of a deeper cladistic analysis of the whole family, our observations are not in contrast with Licher's hypothesis. As already pointed out by Nygren (1999) for the ambiguous taxonomic position of the genus Pionosyllis within the sub-family Eusyllinae, the analysis of the reproductive patterns in Syllidae could contribute to a drastic change in the presently accepted taxonomic hierarchy of the family.

\section{ACKNOWLEDGEMENTS}

The work of the authors A. Giangrande and L. Musco was carried out within the MARBEF Network of Excellence "Marine Biodiversity and Ecosystem Functioning", which is funded in the 
Community's Sixth Framework Programme (contract no. GOCE-CT-2003-505446). The above-mentioned authors also wish to thank Marta Chirac for her kind help.

\section{REFERENCES}

Bührmann, C., W. Westheide and G. Purschke. - 1996. Spermatogenesis and sperm ultra-structure in the interstitial syllid Petitia amphophtalma (Annelida, Polychaeta). Ophelia, 45: 201-211.

Daly, J.M. - 1975. Reversible epitoky in the life history of the polychaete Odontosyllis polycera (Schmarda, 1861). J. Mar. Biol. Assoc. U.K., 55: 327-344.

Estapè, S. and G. San Martín - 1991. Descripción de los estolones reproductores de algunas especies de la subfamilia Syllinae (Polychaeta, Syllidae). Misc. Zool., 15: 43-62.

Franke, H.D. - 1999. Reproduction of Syllidae (Annelida: Polychaeta). Hydrobiologia, 402: 39-55.

Franke, H.D. and H.D. Pfannenstiel. - 1984. Some aspects of endocrine control of polychaete reproduction. In: A. Fischer and H.D. Pfannenstiel (eds.), Polychaete reproduction: progress in comparative reproductive biology. Fortschr. Zool., 29: 53-72. Gustav Fischer Verlag, Stuttgart

Franzén, A. - 1956. On spermiogenesis, morphology and the spermatozoon and biology of fertilisation among invertebrates. Zool. Bidr. Uppsala, 31: 355-482.

Franzén, Å. - 1974. Sperm structure in some Polychaeta. In: B.A. Afzelius (ed.), The Functional Anatomy of the Spermatozoon, pp. 267-278. Pergamon Press, Oxford.

Franzén, Å. - 1982. Ultra-structure of spermatids and spermatozoa in three polychaetes with modified biology of reproduction: Autolytus sp, Chitinopoma serrula and Capitella capitata. Int. J. Invertebr. Reprod., 5: 185-200.

Garwood, P.R. - 1991. Reproduction and the classification of the family Syllidae (Polychaeta). Ophelia, 5 (Suppl.): 81-87.

Giangrande, A. - 1997. Polychaete reproductive patterns life cycles and life histories: an overview. Oceanogr. Mar. Biol. Annu. Rev., 35: 323-386.

Giangrande, A., M. Licciano and P. Pagliara - 2000. The diversity of diets in Syllidae (Annelida: Polychaeta). Cah. Biol. Mar., 41: $55-65$.

Giangrande, A., M. Sciscioli, E. Lepore, M. Mastrodonato, P. Lupetti and R. Dallai - 2002. Sperm ultra-structure and spermiogenesis in two Exogone species (Polychaeta, Syllidae, Exogoninae). Invertebr. Biol., 121(4): 339-349.

Gidholm, L. - 1965. On the morphology of the sexual stages, mating and egg-laying in Autolytus (Polychaeta). Zool. Bidr. Uppsala, 37: 1-42.

Gidholm, L. - 1966. On epigamy in Autolytus (Polychaeta), and non-stolonic Sacconereis and Polybostrichus stages. Ark. Zool., 19(4): 135-142.

Glasby, C.J. - 2000. Family Syllidae. In: P.L. Beesley, G.J.B. Ross and C.J. Glasby (eds.), Polychaetes \& Allies: The Southern Synthesis. Fauna of Australia. Vol. 4A Polychaeta, Myzostomida, Pogonophora, Echiura, Sipunculida, pp. 161167. CSIRO Publishing. Melbourne.

Heacox, A.E. and P.C. Schroeder - 1981. A light- and electronmicroscopic investigation of gametogenesis in Typosyllis pulchra (Berkeley and Berkeley) (Polychaeta: Syllidae) I. Gonad structure and spermatogenesis. Cell Tissue Res., 218: 623-639.

Jamieson, B.G.M. and G.W. Rouse - 1989. The spermatozoa of the Polychaeta (Annelida): an ultrastructural review. Biol. Rev., 64: 93-157.

Kuper, M. and W. Westheide - 1997. Sperm ultra-structure and spermatogenesis in the interstitial Polychaete Sphaerosyllis hermaphrodita (Syllidae: Exogoninae). Invert. Reprod. Dev., 32(3): 189-200.
Licher, F. - 1999. Revision der Gattung Typosyllis Langerhans, 1879 (Polychaeta: Syllidae). Morphologie, Taxonomie und Phylogenie. Abh. Senckenb. Natforsch. Ges., 551: 1-336.

Malaquin, A. - 1893. Recherches sur les Syllidiens. Morphologie, anatomie, reproduction, développement. Mém. Soc. Sci. Agric. Lille, 18: 1-477.

Mastrodonato, M., M. Sciscioli, E. Lepore, M. Gherardi, A. Giangrande, D. Mercati, R. Dallai and P. Lupetti - 2003 External gestation of Exogone naidina Oersted, 1845 (Polychaeta, Syllidae): ventral attachment of eggs and embryos. Tissue Cell., 35(4): 297-305.

Millonig, G. - 1976. Laboratory manual of biological electron microscopy, M. Saviolo (ed.), pp. 1-67. Vercelli.

Musco, L. and A. Giangrande - 2005. Mediterranean Syllidae (Annelida: Polychaeta) revisited: species diversity, biogeography and faunal fidelity to environmental features. Mar. Ecol. Prog. Ser., 304: 143-153.

Nygren, A. - 1999. Phylogeny and reproduction in Syllidae (Polychaeta). Zool. J. Linn. Soc., 126(3): 365-386.

Okada, Y.K. - 1929. Regeneration and fragmentation in the Syllidian Polychaetes (studies on the Syllidae II). Arch. Entwicklungsmech. Organismen, Berlin, 115: 542-600.

Okada, Y.K. - 1937. La stolonisation et les caracteres du stolon chez les Syllidiens Polychètes. Jpn. J. Zool., 7: 441-490.

Patti, P., M.C. Gambi and A. Giangrande - 2003. Preliminary study on the systematic relationships of Sabellinae (Polychaeta: Sabellidae), based on the $\mathrm{C} 1$ domain of the $28 \mathrm{~S}$ rDNA, with discussion of reproductive features. Ital. J. Zool., 70: 269-278.

Potts, F.A. - 1911. Methods of reproduction in the syllids. Fortschr. Zool., 3: 1-72.

Rice, S.A. - 1992. Polychaeta: Spermatogenesis and Sperm structure. In: F.W. Harrison and S. Gardiner (eds.), Microscopic Anatomy of Invertebrates Vol. VII (Annelida), pp. 129-151. Wiley-Liss Inc. New York.

San Martín, G. - 2003. Annelida, Polychaeta II: Syllidae. In: M.A Ramos Sánchez, J.Alba Tercedor, X. Bellés i Ros, J. Gosálbez i Noguera, A. Guerra Sierra, E. Macpherson Mayol, F. Martín Piera, J. Serrano Marino and J. Templado González (eds.), Fauna Ibérica, Vol 21, pp. 1-554. Museo Nacional de Ciencias Naturales. CSIC, Madrid.

San Martín, G. - 2005. Exogoninae (Polychaeta: Syllidae) from Australia with the description of a new genus and twenty-two new species. Rec. Aust. Mus., 57(1): 39-152.

Schiedges, K.L. - 1979. Reproductive biology and ontogenesis in the polychaete genus Autolytus (Annelida: Syllidae): observations on laboratory cultured individuals. Mar. Biol., 54: 239-250.

Schiedges, K.L. - 1980. Morphological and systematic studies of an Autolytus population (Polychaeta, Syllidae, Autolytinae) from the Oosterschelde estuary. Neth. J. Sea Res., 14(2): 208-219.

Schroeder, P. and C.O. Hermans - 1975. Annelida: Polychaeta. In A.C. Giese and J.S. Pearse (eds.), Reproduction of Marine Invertebrates. Vol. III. Annelids and Echiurans, pp: 1-213. Academic Press, New York.

Westheide, W. - 1984. Genesis and structure of the modified spermatozoon in the interstitial polychaete Hesionides arenaria (Annelida). Biol. Cell., 50: 53-66.

Wissocq, J.C. - 1970a. Évolution de la musculature longitudinale dorsale et ventrale au cours de la stolonisation de Syllis amica Quatrefages (Annélide Polychète). I. Muscles du ver asexuée et muscles du stolon. J. Microsc., 9: 355-388.

Wissocq, J.C. - 1970b. Évolution de la musculature longitudinale dorsale et ventrale au cours de la stolonisation de Syllis amica Quatrefages (Annélide Polychète). II. La dédifférenciation. $J$. Microsc., 9: 1049-1074.

Wissocq, J.C. - 1970c. Évolution de la musculature longitudinale dorsale et ventrale au cours de la stolonisation de Syllis amica Quatrefages (Annélide Polychète). III. La dégénérescence. $J$. Microsc., 9: 1075-1088.

Received April 11, 2006. Accepted June 27, 2006.

Scient. ed.: M.P. Olivar.

Published online October 23, 2006. 